\title{
Is the Relationship between Employees' Psychological Empowerment and Employees' Job Satisfaction Contingent on the Transformational Leadership? A Study on the Yemeni Islamic Banks
}

\author{
Abdullah Kaid Al-Swidi ${ }^{1}$, Mohd Kamal Mohd Nawawi ${ }^{1}$ \& Asma Al-Hosam ${ }^{2}$ \\ ${ }^{1}$ School of Quantitative Sciences, College of Arts and Sciences, Universiti Utara Malaysia, Sintok, Malaysia \\ ${ }^{2}$ Tadhamoon International Islamic Bank, Sana'a, Yemen \\ Correspondence: Abdullah Kaid Al-Swidi, School of Quantitative Sciences, College of Arts and Sciences, \\ Universiti Utara Malaysia, Sintok, Malaysia. Tel: 60-12-466-2754. E-mail: swidi@uum.edu.my
}

Received: November 15, 2011

Accepted: April 27, $2012 \quad$ Published: August 1, 2012

doi:10.5539/ass.v8n10p130

URL: http://dx.doi.org/10.5539/ass.v8n10p130

\begin{abstract}
The construct of employees' job satisfaction has been gaining an increasing scholarly attention as one of the crucial determinants of organizational effectiveness and success. Specifically, it has been very much acknowledged by both researchers and academics that employees are the most valuable assets of an organization and play the crucial role in achieving its overall objectives. These arguments justify the attention given to studying the psychological characteristics of employees and what determine their job satisfaction that impacts the organizational performance. In addition to that, transformational leadership has been proven to have a significant effect on the employees' job satisfaction through enhancing the employees' perception of empowerment. Despite this fact, the dynamic role of transformational style on enhancing the level of satisfaction among the empowered individuals has been greatly neglected. It has been, also, proven in the literature that employees' satisfaction directly affects the customers' satisfaction and subsequently the overall organizational performance. In Yemen, as it the case on many developing countries, employees of an organization should be satisfied as the first step to achieve a better organizational performance associated with customers' satisfaction. The poor performance of Yemeni banks, as customer-oriented business, can be, somehow, attributed to the low level of employees' job satisfaction. This paper, however, aims to examine the joint effect of employees' psychological empowerment and transformational leadership on the employees' job satisfaction. To achieve this purpose, responses of a sample of 160 employees from the Yemeni Islamic banks have been examined. The findings of this study confirmed the direct effect of employees' psychological empowerment and transformational leadership on the employees' job satisfaction. On the other hand, the moderating effect of transformational leadership on the relationship between employees' psychological empowerment and the employees' job satisfaction was not supported. These findings were, finally, discussed in the lights of the limitations of the study and future research directions were offered.
\end{abstract}

Keywords: psychological empowerment, transfromational leadership, employees' job satisfaction, islamic banks, Yemen

\section{Introduction}

The current changing, uncertain and competitive business environment has created great challenges for organizations striving to grow or even survive. In other words, currently, all kinds of organizations have been facing many challenges regardless of their size, technology adopted, and highly strategic policies used (Ramlall, 2004). Additionally, the fast paced technological advancements changed all aspects of life and the whole world has diversified the choices for job seekers. However, the availability of jobs cross boarders has affected the stability of talented job seekers who are always attracted by high promising jobs causing what is so called as brain drain. Not only for the talented employees but also other less experienced can also seek better jobs anywhere in the world. In this situation, the business environment can be characterized as instable especially from human resources perspective.

Due to the open global market business environment and subsequent global attractive job opportunities, the issue of employees' job satisfaction has been gaining an increasing attention by both academicians and practitioners to 
retain the talented and loyal employees. It was also argued that there is a correlation between employees' job satisfaction and the financial success for organizations (Maister, 2001). Moreover, the cost of turnover of employees from their organizations has been reported to cause big losses. For example, Fitz-enz (1997) argued that the average direct as well as indirect loss by company for every ten managers and professional employees is about $\$ 1$ Million. Apparently, the voluntary leave has been one of the major problems in most of the ASEAN countries such as Malaysia, Thailand, and Taiwan (Ahmed \& Bakar, 2003). Furthermore, Ramlall (2004) stated that job-hopping has become a culture in Asian countries.

The necessity to retain talented and experienced employees' has attracted both practitioners and academicians to pay an increasing attention to study the determinants of employees' job satisfaction. In other words, scholarly attention has been directed to study the determinants of employees' job satisfaction not only in terms of financial benefits but also in terms of other human aspects of jobs.

To achieve short as well as long-term objectives of an organization, all the employees' ideas, creativity, and opinions are needed. Moreover, the efforts in an organization should be exerted to create and establish the passion in the employees towards their jobs. However, $t$ has been emphasized that it is possible to purchase man power but it is impossible to purchase their hearts and minds (Covey, 1997). Therefore, an organization to be able to utilize the available intellectual skills and knowledge resourced in the employees, all the employees should have and acquire the feeling of belonging to the organization and match their objectives with the overall objectives of their organization.

The strong contribution of employees to an organization's success is academically as well as practically acknowledged since the employees can have a customer-centric approach in their work and related interactions. Therefore, if the employees are satisfied, they are more likely to show higher customer-oriented behavior and significantly contribute to the overall performance. The on-going concern of an organization is how to ensure high level of job satisfaction among their employees.

In the literature of human resource management, an extensive attention has been given to explore the effect of employees' satisfaction on productivity, turnover, customer loyalty, and profitability. Unfortunately, notwithstanding the attention given to the employees' satisfaction in the literature, the importance of job satisfaction on the performance has been neglected in the extant OM literature (Boudreau, 2004).

Additionally, many variables have been studied as determinants of the employees' job satisfaction and this area of research is still waiting for further contributions. Therefore, the aim of this paper is to examine the effects of empowerment and transformational leadership on the employee satisfaction. The empirical literature revealed that if the organization ensured high level of employee satisfaction, a high level of customer satisfaction and then profitability can be achieved (Levine, 1995).

Regarding the Yemeni business environment, Yemeni banks have been reported to have many problems threatening their overall organizational performance. For example, according to the Yemen Country Profile Report (2009), the Yemeni banking system is very weak to back up the development process of the country. In addition to that, the Mayor of the Central Bank of Yemen stated that the Yemeni people save their money at homes and don't trust or reluctant to deal with banks. This fact was reflected in the limited annual banks' transactions that were found to be only 600 thousand bank accounts, which represent only 2.7 per cent of the population, and no more than 500-600 thousand annual circulated checks. These facts have been confirmed by a recent study conducted by the Malaysian company SIRIM Berhad (2010) in its effort to design a strategic plan for the industrial development in Yemen. As reported by this study, only 4 per cent of the entire Yemeni populations have banking accounts (Saeed, 2011).

For the Yemeni economy, SMEs were reported to have significant importance since they constitute of about $99.6 \%$ of all business organizations and contribute more than $7.2 \%$ to the GDP of the country employing more than 485,000 workers (Ministry of Planning and International Cooperation MOPIC, 2004). Despite this important role of SMEs, the major challenge of SMEs' survival and growth in the Yemeni business environment is to have an access to the financial resources required for the operational needs. Specifically, in a survey conducted in 2004 by the Ministry of Planning and International Cooperation, the results showed that 12.2 per cent of SMEs working in Yemen lack the access to the financial resources for successful operation (Ministry of Planning and International Cooperation MOPIC, 2004).

In an attempt to identify the reason behind that, Saeed (2011) attributed that to the lack of banking culture resulted from very poor customer-focused businesses. In relation to that, Al-Swidi and Mahmood (2011) argued that one of the most serious causes of the Yemeni banks' problems is the lack of customer-focus strategies being practiced by the Yemeni banks. As a result of that, the Yemeni banks have failed to gain the trust of the Yemeni customers to do 
their transactions through banks. Without the ability of Yemeni banks to attract the Yemeni savers as a source of money, the survival and growth of these banks will be questioned. These threatening forces might be severe if the efforts to open the economy have been success. In other words, after the expected entrance to the World Trade Organization (WTO), there will be a fiercer competition and the structure of the Yemeni business environment will be completely different.

Many previous studies in the literature showed that there is a strong positive relationship between employees' satisfaction and customers' satisfaction (e.g. Bernhardt, Donthub, \& Kennette, 2000; Schneider \& Bowen, 1985; Schneider, White, \& Paul, 1998). From specific perspective, employees' satisfaction has been proven to have a statistically significantly relationship with the service quality and customers' satisfaction leading to enhanced performance and successful strategy implementation (Brown \& Lam, 2008; Yee, Yeung, \& Cheng, 2008). These findings imply that if an organization seeks to achieve high level of customers' satisfaction, the first step is to achieve a high level of employees' satisfaction since employee satisfaction positively affect the customer satisfaction and then the business outcomes.

In his endeavor to identify the difficulties hinder the quality management implementation, Al-Zamany, Hoddell, and Savage (2002) indicated that the poor human resource management practices is considered as one of the main reasons that explain the resistance of changes and technology adoption in the Yemeni business organizations. In fact, the Yemeni employees are, generally, not involved in the decision-making processes, very less empowered, rarely trained, and hence always dissatisfied. Therefore, as this study aims to examine how the empowerment and transformational leadership style can jointly lead to satisfied employees who can contribute significantly to the quality of services provided and then keep the customers satisfied and even loyal.

\section{Employee Job Satisfaction (EJS)}

The issue of employee job satisfaction (EJS) has been widely discussed in the organizational behavior literature. The wealth research work in the literature revealed that the more satisfied the employees, the less the turnover rate and absenteeism. Researchers, however, extended huge research work to identify the determinant of EJS. There has been almost consensus among academicians and practitioners that teamwork environement, job autonomy, leadership style, and the nature of the work can be important determinants of EJS. However, determining the power of each variable towrads EJS might be dependent on the environment. As the EJS has positive and significant effect on employees' productivity, organizations always invest in technology and change their strategies to increase EJS and subsequently productivity. Effective human resource management (HRM) practices play a critical role in increasing the level of EJS and then productivity (Bloom \& Van Reenen, 2007).

Although there have been many definitions of the employee job satisfaction, there is an almost consensus among researchers that it is the feelings developed by employee towards his/her job. Specifically, Spector (1997) defined it as the degree of like or dislike people develop towards their work. Locke (1969), on the other hand, defined job satisfaction as a positive emotional feeling towards his/her job resulted from the comparison between their expectations and actual benefits.

In the past, researchers suggested that job satisfaction comes from the person's feelings towards his/her job rather than the fulfillment of his/her needs (Locke, 1976). Several other determinants of job satisfaction such as reward system, individual differences, self-esteem, and locus of control been examined by many researchers (Lankau \& Scandura, 2002; Chen \& Silverthorne, 2008).

Additionally, EJS is defined by Bullock (2003) as the attitude results from the balance between likes and dislikes connected to job experience. It is also defined by Peptone (1999) as the employees feeling related to four important areas namely, job, management, personal adjustment and social relations. In a similar way, Hop Pock (1996) defined employee satisfaction as a combination of psychological, physiological and environmental circumstances that causes the personal satisfaction with his job. In general, the EJS can be thought of as the output of work environment.

EJS construct has been used to describe the individual attitudes towards some aspects of the work situation. Since the occupation of individuals become social phenomenon, a great and increasing attention given by researchers to the issues related to the job satisfaction.

If the employees are not satisfied in the organization where they work, they surely seek their satisfaction elsewhere. In general, it was concluded by Ting (1997) that job characteristics such as pay, promotional opportunity, task clarity, and skills utilization, as well as organizational characteristics such as commitment, relationship with supervisors, and co-workers have significant effects on job satisfaction. Organizations, that are serious about the job satisfaction, have to tale deliberate steps to develop and maintain a stimulating work 
environment. However, for job satisfaction, there are various dimensions to be considered as vital in explaining the EJS construct. These constructs are important since they influence the way a person feels about his/her job.

As described by Katzwl, Barrett and Parker (1961) that the employees' satisfaction and performance are the output resulted from the interaction between the employees' efforts and the working environment, abilities, and motivation. In addition to that, the EJS can be generated by meeting the employees' expectations and needs from their work (Pepitone, 2006). As previously indicated, due to its significant impact on customer satisfaction and business profitability, the issue of employee satisfaction has been the subject of huge research efforts. In the literature of human resource management, many elements have been reported to be related to the employee satisfaction. Some of these elements are discussed in the following.

HRM practices has been acknowledged to have a significant effect on satisfaction with pay and overall job satisfaction (Petrescu \& Simmons, 2008). Additionally, Davis and Newstrom (1999) described job satisfaction as an experience that has different aspects. Some of the most important aspects related to the work conditions and the nature of work. It has been emphasized that job autonomy, job security, wages and expectation for promotion significantly impact the job satisfaction of employees (Guest, 2004; Silla et al., 2005).

In an attempt to discover the determinant factors of job satisfaction, Garrido et al. (2005) carried out a researchers on sales managers of Spanish industrial companies. Their findings revealed that human resource management practices based on compensation, job autonomy, and empowerment were essential for EJS.

The formation of teams that show high level of cohesivness can be an effective factor that results in job satisfaction. Teamwork culture can help the employees to perform their works and improve their added value outcomes driven by their own plans apart from the enforcement made by the traditional management practices (Dunkerley, 1975). In the current dynamic business environemnt, there should be fast and aligned changes that could be successful only by the emphasis on teamwork spirit and encouragement of changes.

Besides the teamwork culture, leadership can be one of the crucial factors to grow the employees abilities and build their capabilities through establishment of a cuzy work environment full of love and sincerity that create the employees' loyalty and enhance their productivity (Aydin \& Ceylan, 2009). Leadership, generally, refers to the motivation and influence, practiced by competence and skilled person, on the employees and subordinate to achieve overall organizational objectives (Gill et al., 2010).

The complexity, increased volatility of the current business environment, the rapid technological changes, and the hyper-competition in the market rquired organizations to pay more attention to all the human capitals as one of the main resources to be used efficiently to create the competitive advantage. Loyalty and commitment and subsequently high performance of workers are the immediate results of job satisfaction. The previous research study involve a great deal of attention to the job satisfaction as the determinant of employee's performance especially in the uncertain, turbulent and competitive business environment (Khalid \& Irshad, 2010).

To be able to survive in the current competitive market, banks, among other organizations, have to focus on offering high quality products and services at competitively cheap price. However, one of the main determinent of effective banks' performance is the ability of banks to retain their talented, well-trained, and skilled employees(Khalid \& Irshad, 2010).

Additionally, needless to say that the satisfied and loyal employees of any organization are the heart that that supplies the life and ensures the survival. Therefore, top management of an organization has always to generously invest in employee satisfaction and subsequent loyalty. The failure to realize and recognize the importance of human factor in the organization can lead to dissatisfied employees with high rate of turnover that lead to low level of customer satisfaction (Heskett, Sasser, \& Schlesinger, 1997).

It has been widely recognized that successful business leaders today have been paying a great deal of attention to the satisfaction level of their employees, especially customer-contact employees, and their customers more than immediate profits and market share (Jones, 1994). That is to say, to ensure the long-term business effectiveness, profitability, and success, employees' satisfaction is the most important driver. To further elaborate the elements of employees' satisfaction, the following section devoted to explain some of these factors.

\section{Employee Psychological Empowerment (PE)}

Psychological empowerment (PE) in the workplace has been a focus on scholar as well as practical attention since the 1960s due to the civil rights movements. It is the social action process pertaining to an individuals, groups, or organizations to reflect their perceived possession of control over some situational factors in the work environment (Spreitzer \& Doneson, 2007). As posited by Maslow's (1971) theory of self-actualization, an individual who is self-actualized is empowered to the fullest capability based on the percieved level of life 
control. As a results of that, if the employee could not achieve self-actualization will have limited positive performance. In general, unhealthy societies normally resulted in unhealthy people.

As argued by Maslow (1971), people in general have an intrinsic need to have self-determination, autonomy, and hold responsibility to function healthly and grow constantly. It was also, argued that individuals within environment where their personal goals are unachieveable and they are subject to the others' will, will have a decreasing self-esteem and self-worth.

In the early 1960s, Theory X organization has been presented by McGregor (1960). The main assumption of this theory is that the management rigidity and the constant supervision of the employees brought by the opposite effect. If employees are not having the autonomous, not trusted, and nonot involved in the decision making processes, unhealthy work environment and poor functioning willl be resulted. It was also argued by McGregor (1960) that authoritative supervision strategies impede the employees' learning and growth. Additionally, theories of psychological empowerment have implications for work environment since it encourages the positive culture and enhance the employees' job satisfaction.

\subsection{Psychological Empowerment Definition}

It has been widely known in the human resource management literature that empowerment has various definitions that all have implicit agreement regarding its nature. Albeit the agreement regarding the nature of the empowerment, there has been no fully agreed upon definition of empowerment (Peccei \& Rosenthal, 2001). The close relation of employee empowerment to management techniques and instruments, such as motivation, job satisfaction, trust, communication, training and feedback, and delegation highlights the importance of examining the concept and its managerial implications from different perspectives. Researchers approach the psychological empowerment construct from different perspectives. For example, from the behavior and relationship perspective Hales and Klidas (1998) defined empowerment as sharing knowledge and the level of information and power with subordinates.

Conger and Kanungo (1988) related the empowerment, as a motivational concept, to self-efficacy and therefore defined empowerment as the improvement of the self-efficacy feeling of employees. Moreover, they argued that administrative implementation of the empowerment will not be enough alone since it makes up only a small portion of empowerment itself. To deeply define the concept, Thomas and Velthouse (1990) highlighted that the empowerment cannot be looked at as one dimensions since administrative implementations and the employees' perceptions should be taken into consideration. However, Thomas and Velthouse (1990) defined empowerment, as the internal motivation, based on four perceptive dimensions namely sense, competence, choice, and impact. Spreitzer (1995), however, incorporated these dimensions in defining the empowerment construct.

Undeniably, both managers and researchers in the management field regard the employees as the main source of competitive advantage and subsequently their empowerment and involvement are the key success factor of any organization (Siegall \& Gardner, 2000). In addition to that, many studies supported the role of employee empowerment in enhancing the organizational commitment (Han, Moon, \& Yun, 2009; Spreitzer \& Mishra, 2002), motivation (Caudron, 1995), performance (Sigler \& Pearson, 2000) and customer satisfaction (Chebat \& Kollias, 2000).

\subsection{Psychological Empowerment Constructs}

The psychological empowerment construct has been derived from the constructs of power and control (Conger \& Kanungo, 1988). The power is interprated In social exchange theory (Blau, 1964; Emerson, 1962; Homans, 1961) as the dependence and interdependence between the players. The power is based on the contingency of the level of performance of the actor and is the result of the behavioral responses of others. In the literature, the primary source of power of an individual over others is based on the job position, personal attributes, his/her expertise, or the opportunity to access to special information (French \& Raven, 1959).

In the literature of human resource management, psychological empowerment as looked at as the relational construct related to the power of control excercised by individuals over the resources. Moreover, psychological empowerment is determined by the extent to which the managers share the power with their subordinate by making available organizational resources (Burke, 1986). In addition, the level of autonomy and the distributed decision-makeing power in an organization indicate the extent to which the employees are empowered.

As a motivational construct, Psychological empowerment is presented in the psychological literature as individuals possess the need to control various life events. Individuals have the need to have a control power with which they can control others, ideas, and actions (McClelland \& Burnham, 1976). In general, the power as a motivational force is reflected in the individual's belief that he/she possesses the skills and resources to be 
self-eficacious. Therefore, the main purpose of effective management strategies should be to strengthen the self-efficacy of the employee.

The literature of empowerment has acknowledged the effect of the quality of relationship between supervisors and supervisee in determining the overall performance of the subordinate (Jha \& Nair, 2008). In other words, if employee is provided high support from the superior, he/ she will have high level of self-efficacy and psychological empowerment. As a result of that, in high self-efficacy business enviornment show high motivation and a positive perception of the work environment (Jha \& Nair, 2008). Moreover, the perceived level of psychological empowerment can influence the trust developed by employees. If such trust has been developed, it fosters the innovative behavior of employees and increase their goal attainment and productivity. In addition to that, psychologically empowered employees can determine work roles, feel capable to successfully accomplish their tasks, influence the decision-making process in the workplace (Yukl \& Becker, 2006). Also, employees with positive performance feedback were the ones who have high level of empowerment and engagement.

In brief, the psychological perspective of empowerment is mainly based on the psychological factors that cause the perception of individuals to feel control over their life sitaurions. The personal self-efficacy is achieved through the motivation that enhance the belief of own capability of individuals to perform their tasks (Conger \& Kanungo, 1988). As posited by Thomas and Velthouse (1990), empowerment is as multidimensional construct comprised of meaningfulness, competence, choice, and impact.

\subsection{The Relationship between PE and Employee Job Satisfaction}

In the human resource management literature, there has been an extensive research work related to the relationship between employee psychological empowerment and their satisfaction. For example, Hechanova et al. (2003) condcuted a study on Filipino service workers and their psychological empowerment. In their study, they found that psychological empowerment has a positive correlation with employees' job satisfaction and subsequently job performance.

In the same research stream, Chen and Chen (2008) conducted a study on Taiwan's state-owned enterprises, it was revealed that psychological empowerment significantly mediates the relationship between the impact of change related to work redesign and organizational commitment. In relation to that, Bhatnagar (2005) carried out a study using the data from Indian managers, the findings of that study supported impact of psychological empowerment on the organizational commitment.

In general, employee empowerment is a broad concept incorporating various activities that if they are practiced according to its proper content they can enhance the level of employee satisfaction and job performance. Many studies strongly emphasized the significant relationship between psychological empowerment and job satisfaction (for example, Aryee \& Chen, 2006; Hechanova, Alampay, \&Franco, 2006; Kuo, Yin, \& Li, 2007; Laschinger Finegan, Shamian, \& Wilk, 2004; Spreitzer, Kizilos, \& Nason, 1997).

Recently, Pelit et al. (2011) examined the effect of empowerment on employee job satisfaction. In their study they studied the effect of psychological and behavioral dimensions of empowerment on the level of employee job satisfaction. For that purpose, they studied the sample of 1854 employees working for five-star hotels in Turkey. Analyzing the data using correlation and regression analysis, the findings of their study supported the positive effect of both empowerment dimensions on the employee job satisfaction.

Based on the previous arguments, this study aimed to test the following hypothesis

\section{H1: Employees Psychological Empowerment (EPE) has a significant effect on the Employees' Job Satisfaction (EJS).}

\section{Transformational Leadership}

\subsection{Definition of Transformational Leadership}

Transformational leadership was initiated by Burns (1978) where it was defined as the ability of leaders to inspire, motivate, and influence the followers to achieve higher than the planned results. It has been widely acknowledged in the organizational literature that higher productivity, lower rate of employee turnover, higher level of job satisfaction, and higher motivation are immediate consequences of transformational leadership more than any other leadership style (Masi \& Cooke, 2000; Sparks \& Schenk, 2001).

In the leadership literature, huge attention has been given to the transformational leadership theory and its relation to the organizational behaviors (Avolio, Bass, \& Jung, 1999; Bass, 1985, 1995, 2000; Hackman \& Johnson, 2004). The transformational leadership theory that measure transformation through the degree to which the leaders' affect the followers was presented building on the work of Burns (1978) and Bass 
(1985).Transformal leaders can acquire the trust, admire, and respect of their followers and motivate them to perform beyond expectations and transform both individuals and organizations (Bass, 1985; Keegan \& Hartog, 2004).

Transformational leadership, according to Bass $(1985,1998)$ and Bass and Avolio (1994), has been studied through four elements of behavior. These elements are known as the four IS and includes individualized consideration, intellectual stimulation, inspirational motivation, and idealized influence. As widely acknowledged in the literature, vision communication is the most important behavior of transformational leadership (Bass et al., 2003). In addition, transformational leader tries always to focus on goal attainment through enhancing the employees' self-confidence.

As emphasized earlier, transformational leadership enhances the employees' confidence to be effective players to the overall organizational effectiveness. Also, it promotes the development of critical and creative thinking skills and being responsible (Sosik, Godshalk, \& Yammarino, 2004). In investigating the hierarchical impact of transformational leadership, Bruch and Walter (2007) noted that there was a difference between upper and lower managers. They concluded that there is a difference between different levels of responsibility. Moreover, it was found that the levels of motivation job satisfaction, commitment either increase or decrease in accordance with the level of self-efficacy of the follower.

\subsection{Dimensions of Transformational Leadership}

As suggested by Bass (1985), transformational leadership can be defined through the following dimensions

\subsubsection{Idealized Influence (Attributes and Behaviors)}

Idealized influence or the charisma is one of the most important elements of transformational leadership concept. It implies that these leaders, with transformational leadership style, are respected, admired, and trusted because of their belief, values, and attitudes. These leaders, moreover, as seen by their followers as role models due to the strong emotional attachments and personal identification between leaders and followers.

Charismatic leadership is posited by Bass (1985) to be the most important element of transformational leadership. Moreover, he believed that charisma of leaders is the vital driver of the transformational leadership process. As stated earlier, Waldman, Bass, and Yammarino (1990) asserted that charismatic leaders influence their employees through communicating the vision, tolerating risk, and challenging the employees' capabilities.

The phase of transformational leadership in which the leaders become role models for their followers is characterized by the situation in which leaders have personal characteristics and demonstrate moral behaviors that attract the follower (Kirkbride, 2006). Moreover, he stressed that transformational leaders operate as role models demonstrate unusual competence, celebrate achievements, and use their power to positively manage the business environment. As the influence process between leaders and followers is not automatic, Yukl (2006) suggested that both leaders and followers make attributions about each other's competence and intentions.

\subsubsection{Inspirational Motivation}

This element implies that leaders, with transformational leadership style, behave in ways that motivate their followers by providing meaning to their work and challenge their capabilities. These leaders focused on building team spirit through well- communicated vision that results in developing the followers' high-confidence, optimism, and enthusiasm to attain their goals.

Contributing to the same research stream, Antonakis et al. (2003) asserted that inspirational motivation provide the employees with the clear sense of purpose and subsequently increases the motivation. Additionally, it has been asserted that inspirational motivation approach of leaders helps employees to visualize the future picture of the organization and prevent the followers from wavering in the organizational change through providing information as to what needs to be done and why (Wu \& Shiu , 2009).

As suggested by Kirkbride (2006), inspirationally motivating leaders have the ability to motivate their follower to achieve higher performance by articulating the future picture that followers can strive towards. Hence, in hierarchical organization structure, leaders should be consistent by convincing their subordinates why they are asked to do things. Once employees believe the inconsistencies in the leaders' behaviors, they are more likely to lack the commitment and job satisfaction.

\subsubsection{Intellectual Stimulation}

Intellectual stimulation element implies that leaders always challenge the status quo by developing the creativity and innovation of the employees through questioning assumptions and reapproaching the old situations in new 
ways. According to this element, employees are encouraged to try new approaches and ideas. Moreover, both leaders and followers are urged to develop their capabilities to recognize, understand, and solve future problems.

Seltzer and Bass (1990) stressed that leaders should have the ability to stimulate learning and challenge the followers' intellectual capabilities by setting higher goals and targets. Intellectual stimulation, according to Bass $(1985,1990)$, results an innate confidence within the employees and this develop the leader. It has been also argued by some researchers that followers' attitudes are positively correlated with the attitudes of the leaders over an extended period of time when they follow the transformational leadership style.

\subsubsection{Individualized Consideration}

This dimension refers to the attention paid by leaders to each individual's needs for growth and achievement. Moreover, leaders play the role of coaches and mentors to develop the individuals' potentials through identifying their individual uniqueness. In order to do that, leaders listen to the individuals and understand their strengths and weaknesses to be able to nourish their abilities and confidence.

As stated by Hater and Bass (1988), transformational leaders exert great strategies to maximize the influence on employees through enhancing motivation, satisfaction, and productivity. As a results, employees supervised by leaders showing high level of intellectual stimulation reported high levels of productivity and satisfaction. In other words, followers who are intellectually stimulated showed high level of confidence on their leaders and their expert power. This expert power produces the desire of followers to be intellectually astute.

According to Bass (1985), leaders are attentive to evaluate their followers and encourage them to excel within their current jobs to be able to hold future positions of high responsibilities. Moreover, as stressed by Bass and Avolio (1990), as the leaders focus on the unique characteristics of each follower, a high level of trust and enthusiasm from subordinates can be produced. As discussed by Bass et al. (2003), the level of individualized consideration depends on the experience of the employee. While less skilled employees should be given close supervision, more experienced should be given high level of autonomy and responsibility.

By and large, leaders who are more concerned about followers and their progress than about personal benefit will have more satisfied and productive followers.

\subsection{The Relationship between the Transformational Leadership and Job Satisfaction}

Leadership has been viewed as one of the main determinants of job satisfaction. It plays a significant role in directing the people and their social interaction in an influencing manner so that they could achieve their and organizational goals (Skansi, 2000). In several countries, there has been numerous research works that supported the positive correlation between leadership and the job satisfaction (Seo et al., 2004; Stordeur et al., 2000; Berson \& Linton, 2005).

It has also been argued that the success and effectiveness of an organization depends mainly on managers and their leadership styles. By adopting appropriate leadership style, managers can enhance the employees' commitment, productivity, and job satisfaction. As viewed by Mosadeghrad (2003a), leadership style is a series of characteristics, managerial attitudes, behaviors, skills, leadership interests, and the reliability of employees in different situations. In other words, it is the ability of a leader to influence his/her employees to perform to their highest potentials. This theoretically, includes the extent to which leaders respect employees, operate honestly, promote efficiently, and establish good and fruitful communication channels with employees (Aronson et al., 2003).

Researchers have been attracted to do research work to identify good leaders and these efforts led to the development of leadership theory. Moreover, studies focused on studying various leadership behaviors and how they can help to influence employees for better organizational outcomes (Kreitner, 1995). Tracing the definition of leadership through the past few decades reveals that there has been a revolution started from classical approaches and culminated with creative and participative approach. The ideas about leadership have changed significantly in the recent years. Ideas about management and leadership have changed considerably in recent years. In fact, the people are well-educated and more articulate and therefore should be more involved and have higher participation at work (Stewart, 1994).

As has been identified in the literature, there are various leadership styles such as autocratic, bureaucratic, laissez-faire, charismatic, democratic, participative, situational, transactional, and transformational leadership (Mosadeghrad, 2003a). However, no one can claim that a specific leadership style can result in an effective form of organizational behavior. That is, no one cure for all diseases and, therefore, different situations need different leadership style and leaders should know when to exhibit a specific approach. 
Based on the view of Bass's (1989) about leadership, it is suggested that transformational leadership might enhance the job satisfaction through the sense of intellectual stimulation. In addition to that, transformational leaders encourage their employees to take more responsibilities and autonomy that provide them with increased level of accomplishment and satisfaction. In the same research line, Judge and Piccolo (2004) conducted a meta-analysis and confirmed the positive influence of transformational leadership on employees' job satisfaction, motivation, and leader effectiveness. It is acknowledged that the characteristics of the context play a significant role in leadership effectiveness (Osborn, Hunt, \& Jauch, 2002). Moreover, the task plays a significant role in motivation as once the task is completed, the employee compares the efforts and rewards with similar work situations.

In hierarchical organizations, powerful people exercise their power to influence others through formal authority, technical expertise, and cultural norms (Mintzberg, 1983). According to Vredenburgh and Brender (1998), exercising the power could be abusive to the followers when the outcomes harm the dignity and affect the deserved rewards. It is even worse when employees perceive that there is an abuse of the power within their organization. That is to say, in an organization, the manager could keep the employees motivated and benefit from their full potential, if they perceive that he looks out for the interest for them.

As the transformational leaders focus on the development of their employees' capabilities, their employees extend their full efforts on doing their jobs as they have the sense that their needs are being taken care of by their superiors. Conversely, the employees under the transactional leadership approach might feel dissatisfied under the reward equity system. Masi and Cooke (2000) in their empirical research work; they compared the effect of both transformational and transactional leadership styles on the follower empowerment, motivation, and commitment to quality. Their findings revealed that while transformational leadership tends to motivate and empower the followers, transactional leadership tends to suppress followers outcome quality and productivity.

In the literature of human resource management and organizational behavior, there has been an enourmous number of studies conducted to examine the influence of leadership styles on employees' job satisfaction in the global context. For example, in a study conducted by Jabnoun and Al Rasasi (2005), the aim was to examine the effect of transformational and transactional leadership styles on employees' job satisfaction of hospitals in the UAE. The sample were colledted from six random hospitals to responde to set of items adopted from the Multifactor Leadership Questionnaire developed by Avolio and Bass (1991). The results indicated that employees that have leaders with high rate of charisma, intellectual stimulation, and individualized consideration were more satisfied than others. The results also showed that employees were also satisfied with the contingent reward of transactional leadership.

A Similar conclusion was drawn by Al-Hussami (2008) from his study on 192 nurses serving in four private hospitals in the south-eastern United States. His findings supported the positive relationship between transformational leadership style and the job satisfaction of the nurses. Moreover, according to his analysis, transformational leadership accounted for $80 \%$ of the variance of job satisfaction. In addition to that, the results indicated that the nurses were less satisfied with salary, work conditions, and organizational support.

Similarly, in a study conducted by Ramey (2002), he examined the impact of leadership styles on employees' job satisfaction amongst 7,190 nurses selected randomly many hospitals in Appalachian state. The findings of the study supported the existence of a significant positive relationship between transformational leadership style and employees' job satisfaction and a negative significant relationship between transactional leadership style and employees' job satisfaction. Moreover, the majority of the nurses preferred the transformational leadership styles over the transactional leadership style.

Using the data collected from 140 sport administrators in South Africa, Naidoo (2008) conducted aimed to examine the impact of leadership styles on job satisfaction. His findings revealed that the respondents were satisfied with transformational leadership style practiced by their superiors.

To identify the main factors affecting employees' job satisfaction, Mosadeghrad and Yarmohammadian (2006) carried out a study in Asfahan University Hospitals. The data of the study were collected from 814 employees and managers whom were randomly selected. The results indicated that employees were less satisfied with benefits and salaries, recognition and communication, and work conditions. However, the employees demonstrated more satisfaction on people-oriented leadership style practiced by managers.

In investigating the impact of task-oriented and people-oriented leadership styles on the employees job satisfaction, Bartolo and Furlonger (2000) carried out his study based on a random sample of 56 fire fighters in Victoria and New South Wales, Australia. However, the results revealed that there were positive correlations between the two styles of leadership and job satisfaction. In a similar study conducted by Lok and Crawford 
(2004) to find out the effect of task-oriented and people-oriented leadership styles on job satisfaction. The sample of their study consisted of 219 managers from Hong Kong and 118 from Australia. However, the results based on the combined sample showed that the task-oriented leadership style had a positive effect on job satisfaction contrasting the people-oriented leadership style that had a negative effect.

To find out the relationship between leadership styles and employees' job satisfaction, Leary, Sullivan, and McCartney (2002) conducted a study on a sample of 329 employees selected randomly from 11 public higher educational institutions in the state of West Virginia. For their study they utilized three questionnaires, namely, The Leadership Behavior Description Questionnaire (LBDQ) to measure task-oriented and relationship-oriented leadership styles, the Mohrman- Cooke-Mohrman Job Satisfaction Scale (MCMJSS) to measure eight facets of employees' perceptions of intrinsic job satisfaction factors, and a demographic survey. Their findings indicated that there is a significant correlation between task-oriented and relationship-oriented leadership styles and employees' job satisfaction. According to the previous arguments, the following hypothesis was introduced to be empirically tested.

\section{H2: Transformational leadership has a significant effect on the Employees' Job Satisfaction (EJS).}

\section{The Moderating Effect of Transformational Leadership on the Relationship between Psychological Empowerment and Job Satisfaction}

From the definition of transformational leadership, transformational leaders inspire their followers to be beyond their self-interests for the interests of their organization. In this way, Lowe, Kroeck, and Sivasubramanian (1996) claimed that many researchers noted that transformational leadership has a positive strong relationship with the work outcome such as job performance and satisfaction.

Many studies in the literature studied the relationship between transformational leadership and empowerment. For example, Özaralli (2002) studied the effects of transformational leadership on empowerment and team effectiveness from various industries in Turkey. The data for this study were collected from a sample of 152 employees from eight private Turkish organizations. The finding indicates that the transformational leadership has a positive relationship with the employees' empowerment.

In another study conducted by Bartram and Casimir (2007) to investigated the mediating effects of empoyees' empowerment and trust in the leader and the relationship between the transformational leadership style and followers' in-role performance and satisfaction. The findings of the study showed that the effect of transformational leadership style on the in-role performance was mediated by psychological empowerment and trust in the leader. However, the effect of transformational leadership behavior on employees' satisfaction was found to be partially mediated by the trust in the leader.

In their study on the relationship between transformational leadership, empowerment and intention to quit, Avey et al. (2008) studied a sample of 341 working adults from Midwestern University. They used the structural equation modeling techniques to test for the relationship between transformational leadership and empowerment and for the mediating role of empowerment between transformational leadership and intention to quit. However, the results of their study supported that transformational leadership is significantly positively related with employees' empowerment. In the same way, the results also found that employees' empowerment mediated the relationship between transformational leadership and intention to quit.

Avolio et al. (2004) stated that empowering employees is the essence of transformational leadership in order to achieve the overall organizational goals. Hence, employees need to be empowered by their leaders and; moreover, encouraged to take brave initiatives, stimulate innovation, and cope with uncertainties (Spreitzer, 1995).

More importantly, transformational leadership enhances the followers' energy by providing them an exciting future vision rather than by adopting the reward and punishment system. Beyond that, transformational leaders inspire their followers and build their self-confidence by altering their aspirations, needs and values to be able to reach their full potentials. Also, through spreading out the spirit of team work, transformational leaders can high their followers' enthusiasm, optimism, integrity, high their moral standards, enhance their self-efficacy, and provide more challenging work environment. In doing that, transformational leaders challenge their followers' values, beliefs, and minds to think about things in more creative ways and to take more responsibilities to perform their jobs and achieve higher level of satisfaction.

Despite the enormous number of studies examining the relationship between transformational leadership and psychological empowerment (Avey et al., 2008; Avolio et al., 2004; Özaralli, 2002), the extent to which transformational leadership style practiced by managers can help empowered employees to be satisfied is still 
neglected. Therefore, this study aimed to bridge this gap in the literature by examining the moderating effect of transformational leadership style the relationship between empowerment and employees' satisfaction. Hence the following hypothesis was introduced to be empirically tested.

H3: Transformational leadership moderates the relationship between Employees Psychological Empowerment (EPE) and Employees' Job Satisfaction (EJS).

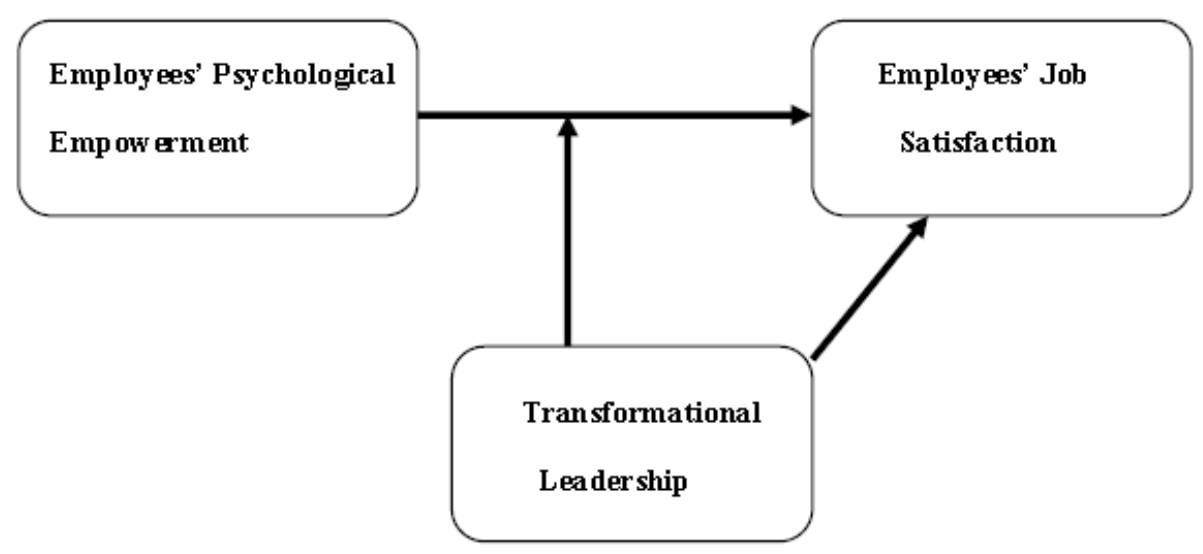

Figure 1. Research framework

\section{Research Methods}

\subsection{Sampling and Data Collection Procedures}

The data for the study were collected using self-administrated survey questionnaires. For that, the questionnaires were distributed to the employees in the Islamic bank branches in Sana'a, the capital of Yemen where the majority of Islamic banks are located. More specifically, questionnaires were distributed to employees in the four banks, namely Tadhamoon Islamic International bank, Saba Islamic bank, Islamic bank for Development and Investment, and Shamil bank of Yemen and Bahrain. Out of 202 questionnaires distributed, 170 questionnaires were returned of which 160 questionnaires (79\%) were usable and brought in for further analysis.

\subsection{Measurements of the Variables}

As discussed earlier, this study aimed to examine the integrated relationship among employees' psychological empowerment, transformational leadership, and employees' job satisfaction. To be able to achieve the aforementioned objective, this study employed the existent measures of these variables in the literature as discussed in the following.

Employees' job satisfaction construct was measured using the 9-item Likert scale measure of Spector (1985). This measure focuses in measuring the level of satisfaction of employees regarding the pay, promotion, work, supervisor, and co-workers.

Similarly, employees' psychological empowerment was measured using 12-item Likert scale adopted from Spreitzer (1995). This measure focuses on the perception of employees regarding the four dimensions of psychological empowerment, namely, meaningfulness, competence, self-determination, and impact.

Finally, to measure the transformational leadership practiced by managers in the Yemeni banking industry, 15-item Likert scale measure was used with items adopted from Rafferty and Griffin (2004). This measure was originally designed to measure the four dimensions of the construct, namely, idealized influence; inspirational motivation; intellectual stimulation; and individualized consideration. 


\subsection{The Goodness of the Measure}

In order to generate valid and reliable results, reliability and validity analysis were performed prior to embarking to test the hypotheses of the study.

\subsubsection{Reliability of the Measure}

To measure the internal consistency of the items used to measure each variable, Cronbach's alpha was used as suggested by Hair et al. (2010). Table 3, however, illustrates that all the variables possess an acceptable level of internal consistency as Cronbach's alpha ranged from 0.794 to 0.941 more than 0.7 confirming the reliability of the instrument used as suggested by Nunnally (1987) and Hair et al. (2010).

\subsubsection{Validity of the Measure}

To capture the dimensions of employees' job satisfaction, Principle Component Analysis (PCA) with varimax rotation was employed. Based on the results of factor analysis, KMO was found to be 0.786 greater than 0.6 and the Bartlett's test of sphericity was significant indicating the factorability of the dimensions. The nine items of employees' job satisfaction construct were found to load on two factors with eigenvalues greater than one. These factors explained $57.25 \%$ (cumulative variance explained (CVE)) of the variance in the employees' job satisfaction construct. The results of the factor analysis were reported in Table 1 below. According the loaded items, the two factors were named as Satisfaction on Pay and Promotion (SPP) and Satisfaction on Supervision and Co-workers (SSC) respectively.

Similarly, FA was conducted to identify the factors underlying the items representing psychological empowerment construct. The KMO was found to be 0.798 exceeding 0.6 with significant Bartlet's test was significant indicating the factorability of the dimensions. The factor loadings of the items on the extracted factors indicated that there were three factors underlying the construct and accounting for $68 \%$ of its variance. Originally, the psychological empowerment construct, based on the literature, has four dimensions namely, meaningfulness, competence, self-determination, and impact. Based on the items loaded on the three factors, names were assigned to the factors as meaningfulness and competence, self-determination, and impact.

Finally, to identify the factors underlying the items measuring the transformational leadership, the items were sent to the factor analysis techniques. The KMO was found to be 0.909 far above the recommended limit of 0.5 and the Bartlett's test was significant (Hair et al., 2010). Instead of the four dimensions identified in the literature for the transformational leadership construct, only two dimensions were identified as a result of the analysis.

Initially, the literature of leadership emphasized on the four (I)s dimensions namely, idealized influence, individualized consideration, inspirational motivation, and intellectual stimulation. However, this study identified only two factors that were named according to the content of the items as inspirational motivation and individualized consideration as evidenced in Table 1.

\section{Analysis and Results}

\subsection{Sampling Profile}

As illustrated in Table 2, the respondents were categorized based on the demographic variables. The majority of the respondents were male $84.4 \%$ while the remaining $25.6 \%$ were female. According to the age group, $82 \%$ of the respondents were aged between 25 and 35 years. In general, the majority of the respondents are youth and the percentage of those aged more than 35 is $5.6 \%$. In terms of the educational level, the majority of the respondents were college graduates constituting $72 \%$ and $10 \%$ had postgraduate degrees.

The results also showed that the majority of the employees had business major and specialization with percentage of $62.5 \%$ compared to $37.5 \%$ with non-business qualifications. From experience point of view, Table 2 showed that most of the employees were less than three years in experience (57.5\%). Generally, as the results indicate, only $5.6 \%$ of the respondents had experience more than 10 years. 
Table 1. Factor analysis results

Job satisfaction

\begin{tabular}{|c|c|c|}
\hline \multirow{2}{*}{ Code } & \multicolumn{2}{|c|}{ Factors } \\
\hline & SPP & SSC \\
\hline SW1 & 0.830 & \\
\hline SS1 & 0.822 & \\
\hline SP2 & 0.742 & \\
\hline SP1 & 0.700 & \\
\hline $\mathrm{SC} 1$ & & 0.785 \\
\hline $\mathrm{SC} 2$ & & 0.785 \\
\hline $\mathrm{SC} 3$ & & 0.652 \\
\hline SS2 & & 0.625 \\
\hline SW2 & & 0.580 \\
\hline Eigenvalue & 3.449 & 1.703 \\
\hline $\mathrm{VE} \%$ & 38.325 & 18.925 \\
\hline Reliability & 0.799 & 0.743 \\
\hline KMO & 0.786 & \\
\hline Overall VE\% & 57.251 & \\
\hline Chi Square & 440.545 & \\
\hline Significance & 0.000 & \\
\hline
\end{tabular}

SSP: Satisfaction on pay and Promotion

SSC: Satisfaction on Supervision and co-

workers

Employees' Psychological Empowerment

\begin{tabular}{|c|c|c|c|}
\hline \multirow{2}{*}{ Code } & \multicolumn{3}{|c|}{ Factors } \\
\hline & EMC & ESD & EI \\
\hline EM1 & 0.847 & & \\
\hline EM2 & 0.800 & & \\
\hline EM3 & 0.796 & & \\
\hline $\mathrm{EC} 1$ & 0.749 & & \\
\hline $\mathrm{EC} 2$ & 0.694 & & \\
\hline $\mathrm{EC} 3$ & 0.538 & & \\
\hline ESD2 & & 0.885 & \\
\hline ESD1 & & 0.784 & \\
\hline EI1 & & 0.636 & \\
\hline $\mathrm{EI} 2$ & & & 0.880 \\
\hline $\mathrm{EI} 3$ & & & 0.762 \\
\hline ESD3 & & & 0.691 \\
\hline Eigenvalue & 4.976 & 1.956 & 1.220 \\
\hline $\mathrm{VE} \%$ & 41.466 & 16.3 & 10.163 \\
\hline Reliability & 0.869 & 0.743 & 0.772 \\
\hline $\mathrm{KMO}$ & 0.798 & & \\
\hline Overall VE\% & 67.929 & & \\
\hline Chi Square & 1016.62 & & \\
\hline Significance & 0.000 & & \\
\hline
\end{tabular}

Transformational leader ship

\begin{tabular}{|c|c|c|}
\hline \multirow{2}{*}{ Code } & \multicolumn{2}{|c|}{ Factors } \\
\hline & TLIM & TLIC \\
\hline TLII1 & 0.811 & \\
\hline TLIS1 & 0.765 & \\
\hline TLII4 & 0.688 & \\
\hline TLIC3 & 0.658 & \\
\hline TLIM 3 & 0.655 & \\
\hline TLIM4 & 0.626 & \\
\hline TLIC1 & 0.615 & \\
\hline TLII2 & 0.548 & \\
\hline TLIS2 & & 0.821 \\
\hline TLIM2 & & 0.814 \\
\hline TLIC2 & & 0.704 \\
\hline TLIS 3 & & 0.675 \\
\hline TLIM 1 & & 0.576 \\
\hline TLIC4 & & 0.565 \\
\hline Eigenvalue & 7.991 & 1.116 \\
\hline $\mathrm{VE} \%$ & 57.081 & 7.97 \\
\hline Reliability & 0.911 & 0.884 \\
\hline $\mathrm{KMO}$ & 0.909 & \\
\hline Overall VE\% & 65.051 & \\
\hline Chi Square & 1627.99 & \\
\hline Significance & 0.000 & \\
\hline
\end{tabular}

Table 2. Respondents' profile

\begin{tabular}{llcc}
\hline Demographic Variable & Category & Frequency & Percent \% \\
\hline Gender & Male & 135 & 84.4 \\
& Female & 25 & 15.6 \\
\cline { 2 - 4 } & Total & 160 & 100.0 \\
\hline \multirow{2}{*}{ Age } & Less than 25 & 20 & 12.5 \\
& between 25 and 30 & 65 & 40.6 \\
& between 30 and 35 & 66 & 41.3 \\
& More than 35 & 9 & 5.6 \\
\cline { 2 - 4 } & Total & 160 & 100.0 \\
\hline Education level & High School & 16 & 10.0 \\
& Community College & 4 & 2.5 \\
& College Degree & 115 & 71.9 \\
& Master or PhD & 16 & 10.0 \\
& Others & 9 & 5.6 \\
\cline { 2 - 4 } & Total & 160 & 100.0 \\
\hline Specialization & Business & 100 & 62.5 \\
& Non-Business & 60 & 37.5 \\
\cline { 2 - 4 } & Total & 160 & 100.0 \\
\hline \multirow{2}{*}{ Working Experience } & Less than 3 years & 92 & 57.5 \\
& Between 3 and 5 years & 33 & 20.6 \\
& Between 5 and 10 years & 27 & 16.9 \\
& More than 10 years & 9 & 5.6 \\
\cline { 2 - 4 } & Total & 160 & 100.0 \\
\hline
\end{tabular}




\subsection{Descriptive Statistics and Correlation}

In fact, all the variables of the study were measured using a 5-point Likert scale ranging from 1 "strongly disagree" to 5 "strongly agree". As can be noticed from Table 3, the mean of most of the variables is above the average ranging from 3.304 to 3.953 with standard deviation ranging from 0.630 to 0.788 indicating above the average recorded perception of the respondents. Moreover, the results in Table 3 indicate that each pairs of the variable psychological empowerment, transformational leadership, and the employees' job satisfaction have significant positive correlation at the 0.01 level of significance.

Table 3. Descriptive Statistics and the correlation among the variables

\begin{tabular}{|c|c|c|c|c|c|c|c|c|}
\hline Variable & Mean & $\begin{array}{l}\text { Std. } \\
\text { Dev. }\end{array}$ & Min. & Max. & $\begin{array}{c}\text { Cronbach's } \\
\text { Alpha }\end{array}$ & (1) & (2) & (3) \\
\hline (1) Empowerment & 3.953 & 0.591 & 1.6 & 5.0 & 0.850 & & & \\
\hline $\begin{array}{l}\text { (2)Transformational } \\
\text { Leadership }\end{array}$ & 3.559 & 0.788 & 1.1 & 5.0 & 0.941 & $.425^{* *}$ & & \\
\hline $\begin{array}{l}\text { (3) Overall } \\
\text { Satisfaction }\end{array}$ & 3.304 & 0.630 & 1.7 & 4.9 & 0.794 & $.367 * *$ & $.527 * *$ & \\
\hline
\end{tabular}

$* * \mathrm{p}<0.01$

\subsection{Hierarchical Regression Analysis}

Prior to performing the hierarchical regression analysis, the assumptions of normality, linearity, homoscedasticity, and error independence were checked to be satisfied as recommended in the literature of multivariate analysis literature (Hair et al., 2010). However, in order to test the postulated hypotheses following the suggestion of Baron and Kenny (1986), the analysis was performed in blocks. To avoid the multicollinearity issue, examining the interaction effect requires that the variables should be centralized before obtaining the interaction terms as recommended by Frazier, Tix, and Barron (2004).

Table 4. Results of hierarchical multiple regression analysis

\begin{tabular}{lccc}
\hline & Model 1 & Model 2 & Model 3 \\
\hline Variables & Controlling variables & Predictors & Interactions \\
\hline Gender & -0.063 & 0.014 & 0.017 \\
\hline Psychological Empowerment & & $0.174^{*}$ & $0.183^{*}$ \\
(EPE) & & & \\
Transformational Leadership (TL) & & $0.458^{* * *}$ & $0.461^{* * *}$ \\
\hline EPE*TL & & & 0.039 \\
\hline F value & 0.626 & 23.617 & 17.714 \\
F Sig. & 0.430 & 0.000 & 0.000 \\
$\mathrm{R}^{2}$ & 0.004 & 0.311 & 0.312 \\
Adjusted $\mathrm{R}^{2}$ & -0.002 & 0.298 & 0.295 \\
$\mathrm{R}^{2}$ change & 0.004 & 0.307 & 0.001 \\
Significant F change & 0.430 & 0.000 & 0.575 \\
\hline
\end{tabular}

$*: \mathrm{p}<0.05 ; * *: \mathrm{p}<0.01 ; * * *: \mathrm{p}<0.001$ 
Based on the results reported in Table 4 above, it can be concluded that employees' psychological empowerment was found to be a positive significant predictor of employees' job satisfaction with indicators $(\beta=0.183 ; t=2.396$; $\mathrm{p}<0.05)$. That is, the more empowered the employee, the higher level of satisfaction he has. This result supported the first hypothesis (H1) of this study. Similarly, transformational leadership was found to have a strong prediction power towards employees' job satisfaction with indicators $(\beta=0.461 ; \mathrm{t}=6.127 ; \mathrm{p}<0.001)$. However, this finding evidenced the second hypothesis $(\mathrm{H} 2)$ postulated earlier in this study. Furthermore, it can be concluded from the results that transformational leadership was found to have a stronger prediction power against the employees' job satisfaction than that of the employees' psychological empowerment.

As illustrated in Table 4, the results showed that the interaction term between EPE and TL was not significant $(\beta=0.039 ; \mathrm{t}=0.575 ; \mathrm{p}>0.05)$ indicating that transformational leadership was not a significant moderating variable on the relationship between employees' psychological empowerment and the employees' job satisfaction. These results revealed that the third hypothesis (H3) was not supported by the findings of the study. Apart from this finding, Figure 2 showed that, although the moderating effect of transformational leadership was not statistically significant, in high transformational leadership situation, any increase in psychological empowerment cause faster increase in the employees' job satisfaction than the case of low transformational leadership situation. Despite the insignificant findings regarding the moderating effect of transformational leadership, its importance in increasing rate of employees' job satisfaction has been acknowledged.

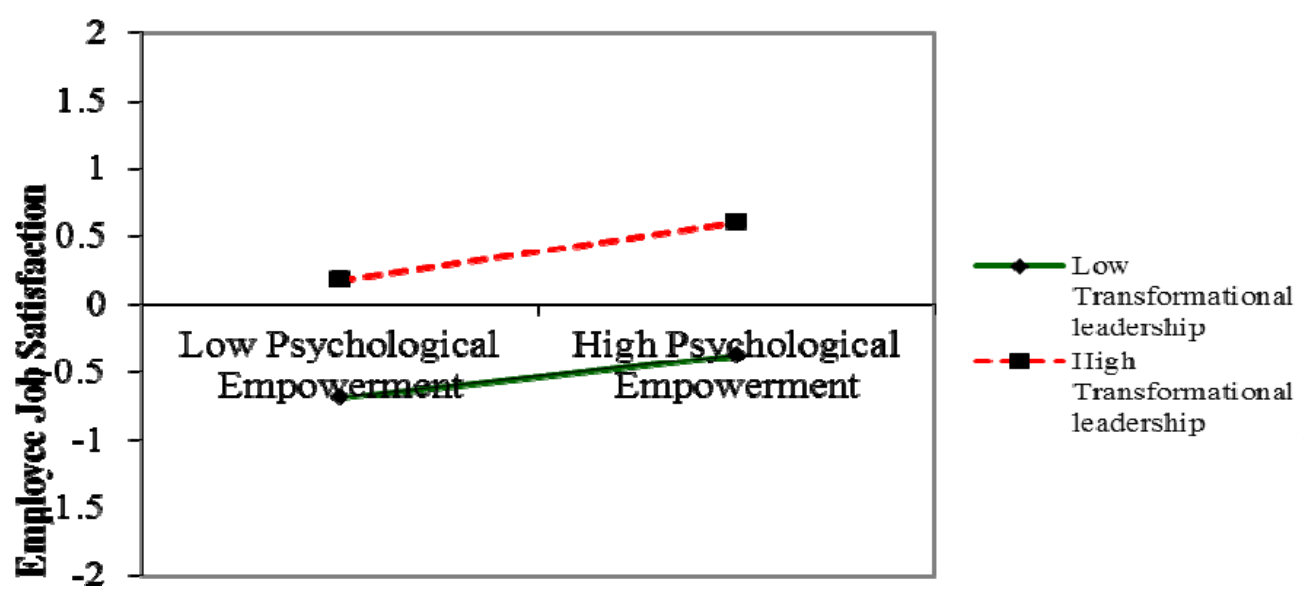

Figure 2. The moderating effect of transformational leadership

\section{Discussion and Conclusions}

Based on the findings of this study, employees' psychological empowerment found to have a positive significant effect on the employees' job satisfaction at the 0.05 level of significance $(\beta=0.183 ; \mathrm{t}=2.396 ; \mathrm{p}<0.05)$. This finding confirmed the positive and significant effect of employees' psychological effect on the employees' level of satisfaction as reported in the previous literature (see e.g. Bordin, Bartram, \& Casimir, 2007; Holdsworth \& Cartwright, 2003; Savery \& Luks, 2001; Seibert, Silver, \& Randolph, 2004; Spreitzer, Kizilos, \& Nason, 1997). This finding indicates that if employees feel empowered, they feel confident to do their jobs and therefore they have high level of job satisfaction.

Moreover, the results of this study also showed that transformational leadership style was found to have a significant positive effect on employees' job satisfaction at the 0.001 level of significance $(\beta=0.461 ; t=6.127$; $\mathrm{p}<0.001$ ). These findings justify the attention given in the literature to transformational leadership as a significant determinant of employees' job satisfaction (Masi \& Cooke, 2000). In addition, these findings were consistent with the findings of many researchers (such as Al-Hussami, 2008; Jabnoun \& Al Rasasi, 2005; Naidoo, 2008; Ramey, 2002). The findings of this study also showed that transformational leadership had a stronger effect on the employees' job satisfaction than that of the employees' psychological empowerment.

On the other hand, the results of this study showed that the interaction term between employees' psychological empowerment and transformational leadership was not significant $(\beta=0.039 ; \mathrm{t}=0.575 ; \mathrm{p}>0.05)$. In other words, this finding, however, indicated that transformational leadership was not a significant moderating variable on the relationship between employees' psychological empowerment and the employees' job satisfaction. This finding 
can be attributed to the lack of healthy leadership practices in the Yemeni business environment in general and in banks in particular as explained in the following.

First, managers themselves lack the authority to lead organizations based on their choice, rather they have to ensure the smoothness of the daily activities and follow the instructions of the owners. In addition to that, Yemeni managers lack the capabilities to play the role of strategic leaders (Al-Zamany et al., 2002).

Second, in relation to the previous argument, Al-Zamany et al. (2002) stated that the management system in Yemeni organizations is not effective to create healthy business environment to utilize all the skills and the intellectual capabilities of the human resources. More specifically, managers have low involvement in setting goals, lack the strategic planning skills, and more seriously often fail to transform the vision and future goals of their organizations to their employees (Al-Zamany et al., 2002).

Last but not least, one of the main reasons of the unhealthy business in Yemen, as argued by Al-Zamany et al. (2002) and Salaheldin (2003), was the lack of human development policies or the poor human resource management system. More seriously, employees in developing countries in general, and in Yemen in particular, are not involved in decision making processes. Additionally, employees in Yemen, in their different levels of responsibility, are not empowered to do their jobs and improve the business processes. In particular, they are not trained to have the capabilities required for successful job performance and there is no incentive system to encourage them to produce high quality and innovative outcomes.

\section{Limitations and Future Research Directions}

As with other studies, this study limited by the limitations of the cross-sectional research design that ignores the dynamic nature of the relationship among the variables undertaking for the study. Moreover, using Likert scale to measure the employees' perceptions regarding many variables could produce biased data since respondents, sometimes; fail to translate accurately their opinions regarding the issues into numbers.

To be able to examine the effect of transformational leadership on the postulated relationship, researchers should conduct similar studies covering wide range of sectors and industries. In addition, future research could follow longitudinal and case study research design to investigate these relationships over long period to describe their dynamicity.

Additionally, future studies may choose to focus on the effect of organizational culture on this relationship. Finally, future studies should pay an increasing attention to explore other organizational factors that could enhance the employees' job satisfaction and to what extent their effect varies cross various context of study.

\section{Acknowledgements}

The authors would like to acknowledge the encouragement and support recieved from Mr. Abdul Gabbar Hayeel the Deputy Chairman of the board of directors of HSA Group of companies and the Chairman of the board of Tadhamon Islamic International Bank in Yemen.

\section{References}

Ahmad K., \& Bakar R. (2003). The association between training and organizational commitment among white-collar workers in Malaysia. International Journal of Training and Development, 7(3), 166-250. http://dx.doi.org/10.1111/1468-2419.00179

Al Hussami, M. (2008). A Study of Nurses' Job Satisfaction: The Relationship to Organizational Commitment, Perceived Organizational Support, Transactional Leadership, Transformational Leadership, and Level of Education. European Journal of Scientific Research, 22(2), 286-295.

Al-Swidi, A. K., \& Mahmood, R. (2011d). Yemeni banking system: Critical issues and future recommended strategies. European Journal of Social Sciences, 20(4), 637-655.

Al-Zamany, Y., Hoddell, S. E. F., \& Savage, B. M. (2002). Understanding the difficulties of implementing quality management in Yemen. The TQM Magazine, 14(4), 240-247. http://dx.doi.org/10.1108/09544780210429852

Antonakis, J. (2003). Why emotional intelligence does not predict leadership effectiveness. The International Journal of Organizational Analysis, 11, 355-361. http://dx.doi.org/10.1108/eb028980

Aronson, K. R., Sieveking, N., Laurenceau, J. P., \& Bellet, W. (2003). Job satisfaction of psychiatric hospital employees: a new measure of an old concern. Adm. Policy Ment. Health, 30(5), 437-489. http://dx.doi.org/10.1023/A:1024645731339 
Aryee, S., \& Chen, Z. X. (2006). Leader-member exchange in a Chinese context: antecedents, the mediating role of psychological empowerment and outcomes. Journal of Business Research, 59, 793-801. http://dx.doi.org/10.1016/j.jbusres.2005.03.003

Avey, J. B., Hughes, L. W., Norman, S. M., \& Luthans, K. W. (2008). Using positivity, transformational leadership and empowerment to combat employee negativity. Leadership and Organizational Development Journal, 29, 110-126. http://dx.doi.org/10.1108/01437730810852470

Avolio, B., Zhu, W., Koh, W., \& Bhatia, P. (2004). Transformational leadership and organizational commitment: mediating role of psychological empowerment and moderating role of structural distance. Journal of Organizational Behavior, 25, 951-1019. http://dx.doi.org/10.1002/job.283

Avolio, Bass, B., \& Jung, D. I. (1999). Re-examining the components of transformational and transactional leadership using the multifactor leadership questionnaire. Journal of occupational and organizations psychology, 72, 169-191. http://dx.doi.org/10.1348/096317999166789

Aydin, B., \& Ceylan, A. (2009). The effect of spiritual leadership on organizational learning capacity. African Journal of Business Management, 3(5), 184-190.

Baron, R. M., \& Kenny, D. A. (1986). The moderator-mediator variable distinction in socialpsychological research: Conceptual, strategic and statistical considerations. Journal of Personality and Social Psychology, 51(6), 1173-1182. http://dx.doi.org/10.1037/0022-3514.51.6.1173

Bartram, T., \& Casimir, G. (2007). The relationship between leadership and follower in-role performance and satisfaction with the leaders: The mediating effects of empowerment and trust in the leader. Leadership \& Organization Development Journal, 28(1), 4-19. http://dx.doi.org/10.1108/01437730710718218

Bass, B. M, Avolio, B. J., Jung, D. I., \& Berson, Y. (2003). Predicting unit performance by assessing transformational and transactional leadership. Journal of Application Psychology, 88(2), 207-224. http://dx.doi.org/10.1037/0021-9010.88.2.207

Bass, B. M. (1985). Leadership and Performance beyond Expectations. The Free Press: New York, NY.

Bass, B. M. (1991). Bass and Stogdill's handbook of leadership: Theory, research and managerial applications. New York: The Free Press.

Bass, B. M. (1995). Theory of transformational leadership redux. The Leadership Quarterly, 6(4), 463-540. http://dx.doi.org/10.1016/1048-9843(95)90021-7

Bass, B. M. (1998). Transformational leadership: Industrial, military, and educational impact. Mahwah, NJ: Erlbaum.

Bass, B. M., \& Avolio, B. J. (1993). Transformational leadership: A response to critiques. In M. M. Chemers \& R. Ayman (Eds.), Leadership theory and research: Perspectives and direction (pp. 49-88). San Diego, CA: Academic Press.

Bass, B.M. (2000). The future of leadership in the learning organization. Journal of Leadership Studies, 7(3), 18-38. http://dx.doi.org/10.1177/107179190000700302

Bernhardt, K. L., Donthub, N., \& Kennettc, P. A. (2000). A longitudinal analysis of satisfaction and profitability. Journal of Business Research, 47(2), 161-171. http://dx.doi.org/10.1016/S0148-2963(98)00042-3

Berson, Y., \& Linton, J. D. (2005). An examination of the relationships between leadership style, quality, and employee satisfaction in $\mathrm{R} \& \mathrm{D}$ versus administrative environments. $R \& D$ Management, 35, 51-60. http://dx.doi.org/10.1111/j.1467-9310.2005.00371.x

Bhatnagar, J. (2005). The power of psychological empowerment as an antecedent to organizational commitment in indian managers. Human Resource Development International, 8, 419-433. http://dx.doi.org/10.1080/13678860500356101

Blau, P. (1964). Exchange and Power in Social Life. New York: Wiley.

Bloom, N., \& Van Reenen, J. (2007). Measuring and Explaining Management Practices Across Firms and Countries. Quarterly Journal of Economics, 122(4), 1341-1408. http://dx.doi.org/10.1162/qjec.2007.122.4.1351

Boudreau, J. W. (2004). Organizational behavior, strategy, performance, and design. Management Science, 50(11), 1463-1476. http://dx.doi.org/10.1287/mnsc. 1040.0283 
Brown, S. P., \& Lam, S. K. (2008). A meta-analysis of relationships linking employee satisfaction to customer responses. Journal of Retailing, 84(3), 243-255. http://dx.doi.org/10.1016/j.jretai.2008.06.001

Bullock, L. M. (2003). The Measurement of Organizational Commitment. Journal of Vocational Behavior, 14, 224-247.

Burke, W. (1986). Leadership as empowering others. In S. Srivastva (Ed.), Executive power (pp. 51-77). San Francisco: Jossey-Bass.

Burns, J. M. (1978). Leadership. Harper \& Row: New York, NY.

Caudron, S. (1995). Create an empowering environment. Personal Journal, 74, 28-36.

Chebat, J. C., \& Kollias, P. (2000). The impact of empowerment on customer-contact employees' role in service organizations. Journal of Service Research, 3(1), 66-82. http://dx.doi.org/10.1177/109467050031005

Chen, J. C., \& Silverthorne, C. (2008). The impact of locus of control on job stress, job performance and job satisfaction in Taiwan. Leadership \& Organization Development Journal, 29(7), 572-654. http://dx.doi.org/10.1108/01437730810906326

Conger, J. A., \& Kanungo, R. N. (1988). The empowerment process: integrating theory and practice. Academy of Management Review, 13(3), 471-552.

Dunkerley, D. (1975). Occupations and society. London and Boston: Routledge \& Kegan Paul.

Emerson, R. (1962). Power-Dependence Relations. American Sociological Review, 27(1), 31-41. http://dx.doi.org/10.2307/2089716

Fitz-enz, J. (2000) The ROI of Human Capital. Amacom, New York.

Frazier, P. A., Tix, A. P., \& Barron, K. E. (2004). Testing moderator and mediator effect in counseling research. Journal of Counselling Psychology, 51(1), 115-134. http://dx.doi.org/10.1037/0022-0167.51.1.115

French, J., \& Raven, B. H. (1959). The bases of social power. In D. Cartwright (Ed.), Studies in social powe (pp.150-167). Ann Arbor, MI: Institute for Social Research.

Garrido, J. L., Rey, P. J., \& Herrera, C.M. (2005). Pre- and post-germination determinants of spatial variation in recruitment in the perennial herb Helleborus foetidus L. (Ranunculaceae). Journal of Ecology, 93, 60-66. http://dx.doi.org/10.1111/j.1365-2745.2004.00955.x

Gill, A., Fitzgerald, S., Bhutani, S., \& Mand, H. (2010). The relationship between transformational leadership and employee desire for empowerment. International Journal of Contemporary Hospitality Management, 22(2), 263-335. http://dx.doi.org/10.1108/09596111011018223

Guest, D. E. (2004). Flexible employment contracts, the psychological contract and employee outcomes: an analysis and review of the evidence. International Journal of Management Review, 5/6(1), 1-19. http://dx.doi.org/10.1111/j.1460-8545.2004.00094.x

Hackman, M. Z., \& Johnson, C. E. (2004). Leadership: a communication perspective. Long Grove: Waveland Press

Hair, J. F., Anderson, R. E., Tatham, R. L., \& Black, W. C. (2010). Multivariate Data Analysis. 7th Ed. Prentice Hall : USA.

Hales, C., \& Klidas, A. (1998). Empowerment in five-star hotels: choice, voice or rhetoric? International Journal of Contemporary Hospitality Management, $10(3), \quad 88-95$. http://dx.doi.org/10.1108/09596119810210260

Han, S. S., Moon, S. J., \&Yun, E. K. (2009). Empowerment, job satisfaction, and organizational commitment: comparison of permanent and temporary nurses in Korea. Applied Nursing Research, 22, 15-34. http://dx.doi.org/10.1016/j.apnr.2009.06.004

Hater, J. J., \& B. M. Bass. (1988). Supervisors' Evaluation and Subordinate's Perceptions of Transformational and Transactional Leadership. Journal of Applied Psychology. http://dx.doi.org/10.1037/0021-9010.73.4.695

Hechanova, M., Alampay, R., \& Franco, E. (2006). Psychological empowerment, job satisfaction and performance among Filipino service workers. Asian Journal of Social Psychology, 9, 72-79. http://dx.doi.org/10.1111/j.1467-839X.2006.00177.x

Heskett, J. L., Sasser, E. W., \& Leonard, S. (1997). The Service Profit Chain. New York: The Free Press. 
Homans, C. E. (1961). Social Behavior: Its Elementary Forms. New York: Harcourt, Brace, Jovanovich.

Homans, G. C. (1958). Social Behavior as Exchange. American Journal of Sociology, 63(6), 597-606. http://dx.doi.org/10.1086/222355

Hop Pock. (1996). Private and Public Sector Managers: An Empirical Investigation to Job Characteristics and Organizational Climate. Journal of Applied Psychology, 71, 247-259.

Jabnoun, N., \& AL Rasasi, A. J. (2005). Transformational leadership and service quality in UAE hospitals. Managing Service Quality, 15 (1), 70-81. http://dx.doi.org/10.1108/09604520510575272

Jha, S. S., \& Nair, S. (2008). Influence of Locus of Control, Job Characteristics and Superior-Subordinate Relationship on Psychological Empowerment: A Study in Five Star Hotels. Journal of Management Research, 8(3), 147-161.

Jones, G. R. (1986). Socialization tactics, self-efficacy and newcomers to organization. Academy of Management Journal, 29, 262-279. http://dx.doi.org/10.2307/256188

Judge, T. A., \& Piccolo, R. F. (2004). Transformational and transactional leadership: A meta-analytic test of their relative validity. Journal of Applied Psychology, 89, 755-768. http://dx.doi.org/10.1037/0021-9010.89.5.755

Katzel, R. A., Barrett, R. S., \& Parker, T. C. (1961). Job Satisfaction, Job Performance and Situational Chrematistics. Journal of Applied Psychology, 45, 65-72. http://dx.doi.org/10.1037/h0040611

Keegan, A. D., \& Hartog, D. (2004). Transformational leadership in a project-based environment: A comparative study of the leadership styles of project managers and line managers. International Journal of Project Management, 22(8), 609-617. http://dx.doi.org/10.1016/j.jproman.2004.05.005

Khalid, S., \& Irshad, M. Z. (2010). Job Satisfaction among Bank Employees in Punjab, Pakistan: A Comparative Study. European Journal of Social Sciences, 17(4), 570-577.

Kirkbride, P. (2006). Developing transformational leaders: the full range leadership model in action. Industrial and Commercial Training, 38(1), 23-32. http://dx.doi.org/10.1108/00197850610646016

Kreitner, R. (1995). Management (6th Ed.). Houghton Mifflin: Boston, MA.

Kuo, H. T., Yin, T. J., \& Li, I. C. (2007). Relationship between organizational empowerment and job satisfaction perceived by nursing assistants at long-term care facilities. Journal of Clinical Nursing, 10, 1-9.

Lankau, M. J., \& Scandura, T. A. (2002). An investigation of personal learning in mentoring relationships: Content, antecedents and consequences. Academy of Management Journal, 45, 779-791. http://dx.doi.org/10.2307/3069311

Laschinger, H. K. S., Finegan, J. E., Shamian, J., \& Wilk, P. (2004). A longitudinal analysis of the impact of workplace empowerment on work satisfaction. Journal of Organizational Behavior, 25(4), 527-571. http://dx.doi.org/10.1002/job.256

Levine, D. I. (1995). Reinventing the Workplace: How Business and Employees Can Both Win. Washington D.C.: The Brookings Institution.

Locke, E. A. (1969). What is job satisfaction? Organizational Behavior and Human Performance, 4, 309-344. http://dx.doi.org/10.1016/0030-5073(69)90013-0

Locke, E. A. (1976). The nature and causes of job satisfaction. In Dunnette, M.D. (Ed.), Handbook of Industrial and Organizational Psychology (pp.1297-1646). Rand McNally, Chicago, IL.

Lowe, K. B., Kroeck, K. G., \& Sivasubramanian, N. (1996). Effectiveness correlates of transformational and transactional leadership: a meta-analytic review of the MLQ literature. The Leadership Quarterly, 7, 385-425. http://dx.doi.org/10.1016/S1048-9843(96)90027-2

Maister, D. H. (2001). Practice what you preach. The Free Press: New York

Masi, R. J., \& Cooke, R. A. (2000). Effects of transformational leadership on subordinate motivation, empowering norms, and organizational productivity. International Journal of Organizational Analysis, 8, 16-47. http://dx.doi.org/10.1108/eb028909

McClelland, D. C., \& Burnham, D. H. (1976). Power is the great motivator. Harvard Business Review, 54, 100-111.

McGregor, D. (1960). The Human Side of Enterprise. New York: McGraw-Hill 
Ministry of Planning and International Cooperation (MPIC). (2004). Policies and programs for the development of SMEs in Yemen. Retrieved Oct 25, 2010, from http://www.mpic-yemen.org/2006/nhdr/arabic/nhdr_rp/nhdr/nhdr4.pdf

Mintzberg, H. (1983). Power in and around organizations. New York, NY: Prentice Hall.

Mosadegh Rad, A. M., \& Yarmohammadian, M. H. (2006). A study of relationship between managers' leadership style and employees' job ssatisfaction. Leadership in Health Services, 19(2), 11-28.

Mosadeghrad, A. M. (2003a). The role of participative management (suggestion system) in hospital effectiveness and efficiency. Research in Medical Sciences, 8(3), 85-94.

Nunnaly, J. C. (1978). Psychometric Theory (2nd ed.). New York: McGraw Hill.

Osborn, R., Hunt, G., \& Jauch, L. (2002). Toward a contextual theory of leadership. Leadership Quarterly, 13, 797-837. http://dx.doi.org/10.1016/S1048-9843(02)00154-6

Ozaralli, N. (2002). Effects of transformational leadership on empowerment and team effectiveness. Leadership and Organization Development Journal, 24(6), 335- 344. http://dx.doi.org/10.1108/01437730310494301

Peccei, R., \& Rosenthal, P. (2001). Delivering customer-oriented behavior through empowerment: an empirical test of HRM assumptions. Journal of Management Studies, 38(6), 831-888. http://dx.doi.org/10.1111/1467-6486.00261

Pelit, E., Yüksel Öztürk, Y., \& Arslantürk, Y. (2011). The effects of employee empowerment on employee job satisfaction: A study on hotels in Turkey. International Journal of Contemporary Hospitality Management, 23(6), 784-802. http://dx.doi.org/10.1108/09596111111153475

Pepitone, J. (2006). Knowledge Leadership: Job Satisfaction. Pepitone Worldwide, White Paper. Retrevied November 1, 2011, from www.pepitone.com/content/know-huma-satisfaction.asp

Petrescu, A., \& I., Simmon, R. (2008) Human resource management practices and workers' job satisfaction. International Journal of Manpower, 29(7), 651-667. http://dx.doi.org/10.1108/01437720810908947

Popton, R. E. (1999). A Casual Model of Turnover for Nurses. Academy of Management Journal, 24, 543-565.

Rafferty, A. E., \& Griffin, M. A. (2004). Dimensions of transformational leadership: Conceptual and empirical extensions. The Leadership Quarterly, 15, 329-354. http://dx.doi.org/10.1016/j.leaqua.2004.02.009

Ramlall, S. (2004). A review of employee motivation theories and their implications for employee retention within organizations. Journal of American Academy of Business, 5(1/2), 52.

Saeed, A. (2011). Only four percent of Yemenis have bank accounts. Yemen Times, 14010. Retrieved Jan 15, 2011, from http://Yementimes.com

Salaheldin, S. I. (2003). The implementation of TQM strategy in Egypt: a field-force analysis. The TQM Magazine, 15, 266-274. http://dx.doi.org/10.1108/09544780310486173

Schneider, B., \& Bowen, D. E. (1985). Employee and customer perceptions of service in banks: Replication and extension. Journal of Applied Psychology, 70 (3), 423-433. http://dx.doi.org/10.1037/0021-9010.70.3.423

Schneider, B., White, S. S., \& Paul, M. C. (1998). Linking service climate and customer perceptions of service quality: Test of a causal model. Journal of Applied Psychology, 83(2), 150-163. http://dx.doi.org/10.1037/0021-9010.83.2.150

Seltzer, J., \& Bass, B. (1990). Transformational leadership: Beyond initiation and consideration. Journal of Management, 16(4), 693-703. http://dx.doi.org/10.1177/014920639001600403

Seo, Y., Ko, J., \& Price, J. L. (2004). The determinants of job satisfaction among hospital nurses: a model estimation in Korea. International Journal of Nursing Studies, 41, 437-483. http://dx.doi.org/10.1016/j.ijnurstu.2003.11.003

Siegall, M., \& Gardner, S. (2000). Contextual factors of psychological empowerment. Personnel Review, 29(6), 703-725. http://dx.doi.org/10.1108/00483480010296474

Silla I., Gracia F., \& Peiró JM. (2005). Job insecurity and health-related outcomes among different types of $\begin{array}{llll}\text { temporary } \quad \text { workers. } & \text { Economic Democracy, } & \text { 26, }\end{array}$ 89-117http://dx.doi.org/10.1177/0143831X05049404

Skansi, D. (2000). Relation of managerial efficiency and leadership styles - empirical study in Hrvatska elektroprivreda. Management, 5(2), 51-67. 
Sosik, J. J., Godshalk, V. M., \& Yammarino, F. J. (2004). Transformational leadership, earning goal orientation, and expectations for career success in mentor-protégé relationships: A multiple level of analysis paper. The Leadership Quarterly, 15, 241-261. http://dx.doi.org/10.1016/j.leaqua.2004.02.003

Sparks, J. R., \& Schenk, J. A. (2001). Explaining the effects of transformational leadership: an investigation of the effects of higher-orders motives in multilevel marketing organizations. Journal of Organizational Behavior, 22, 849-917. http://dx.doi.org/10.1002/job.116

Spector, P. E. (1997). Job Satisfaction: Application, Assessment, Causes and Consequences. London: Sage Publications.

Spreitzer, G. M. (1995). Psychological empowerment in the workplace: Dimensions, measurement, and validation. Academy of Management Journal, 38(5), 1442-1465. http://dx.doi.org/10.2307/256865

Spreitzer, G. M., Kızılos, M. A., \& Nason, S. W. (1997). A dimensional analysis of the relationship between psychological empowerment and effectiveness, satisfaction and strain. Journal of Management, 23(5), 679-704.

Spreitzer, G., \& Doneson, D. (2007). Musings on the past and future of employee empowerment. In T. Cummings (Ed.), Handbook of organizational development (pp. 311-324). Thousand Oaks, CA: Sage.

Stewart, D. M. (1994). Handbook of Management Skills (2nd Ed.). Gower Publishing Co.: Aldershot

Stordeur, S., Vandenberghe, C., \& D'hoore, W. (2000). Leadership styles across hierarchical levels in nursing departments. Nursing Research, 49(1), 37-43. http://dx.doi.org/10.1097/00006199-200001000-00006

Thomas, K. W., \& Velthouse, B. S. (1990). Cognitive elements of empowerment. Academy of Management Review, 15(4), 666-746.

Ting, Y. (1997). Determinants of job satisfaction of Federal Government employees. Public Personnel Management, 26(3),313.

Wu, F. Y., \& Shiu, C. (2009). The relationship between leadership styles and foreign english teachers job satisfaction in adult English Cram Schools:Evidences in Taiwan. The Journal of American Academy of Business, 14(2).

Yee, R. W. Y., Yeung, A. C. L., \& Cheng, T. C. E. (2008). The impact of employee satisfaction on quality and profitability in high contact service industries. Journal of Operations Management, 26(5), 651-668. http://dx.doi.org/10.1016/j.jom.2008.01.001

Yemen Country Profile. (2009). Retrieved September 18, 2009, from http://www.fco.gov.uk/en/about-the-fco/country-profiles/middle-east-north-africa/yemen?profile=geograph $\mathrm{y} \& \mathrm{pg}=5$

Yukl, G. (2006). Leadership in organizations (6th Ed.). Upper Saddle River, NJ: Prentice Hall.

Yukl, G. A., \& Becker, W. S. (2006). Effective empowerment in organizations. Organization Management Journal, 3(3), 210-231. http://dx.doi.org/10.1057/omj.2006.20 